\title{
Towards an Innovation Link between Dynamic Capabilities and Sustainability Strategy: Options for Emerging Market Companies
}

\author{
Richard Lynch \\ Middlesex University Business School \\ The Burroughs, London NW4 $4 B T, U K$ \\ r.lynch@mdx.ac.uk
}

Received 2 October 2017

Accepted 15 January 2018

Published 29 August 2018

\begin{abstract}
Over the last few years, there has been considerable scholarly interest in the strategic management concept of dynamic capabilities. During the same period, sustainability policies and strategies have also become a major focus for many companies. These two areas have resulted in major new innovative opportunities for companies, including those located in emerging markets. However, up to the present time, few studies have attempted to combine the growing scholarly topic of dynamic capabilities with the equally important topic of sustainability strategy in the context of emerging market companies. This paper links these two areas through the theoretical lens of innovation theory. It develops and proposes four main business options for companies, particularly those from emerging markets, from an innovation perspective. The paper contributes new knowledge by identifying and expanding on the innovation strategy links between dynamic capabilities and sustainability strategy. It offers theoretical insights into the nature of that connection in the context of companies from both developed and developing economies.
\end{abstract}

Keywords: Sustainability; dynamic capabilities; innovation strategy; emerging market companies.

\section{Introduction}

Following the early theoretical papers of Teece et al. [1997] and Eisenhardt and Martin [2000] among others, there has been considerable scholarly interest in the strategic management concept of dynamic capabilities. For example, Di Stefano et al. calculated that the yearly number of publications on the topic rose from an average of 32 papers in the years 2000-2005 to 201 papers between the years 20112013 [Di Stefano et al. (2014, p. 307)]. There have also been a number of empirical papers within this total and these have led to at least two meta-analyses of dynamic capabilities in relation to business performance [Fainshmidt et al. (2016); Karna et al. (2016)] with positive results: dynamic resource capabilities are linked to higher business performance. Thus, the concept of dynamic capabilities has become a major focus of scholarly and empirical study over the last few years. This has delivered new 
strategic opportunities for many companies in both developed and emerging economies.

Over a similar time period, there has also been considerable government policy, academic and company interest in the concept of enhancing the sustainability of the Earth's environment. Sustainability strategy has become a major objective at the international, national and company levels. The reason for this increased interest is that "There is now substantial evidence that the greening of economies neither inhibits wealth creation nor employment opportunities. To the contrary, many green sectors provide significant opportunities for investment, growth and jobs." [United Nations Environment Program (2011, p. 16)]. This has relevance both for developed nations and developing economies because governments around the world have committed to the development of increasingly sustainable resources: we live in a global world [UN World Economic Development Survey (2013)]. Sustainability strategy therefore has the potential to provide new business opportunities for many companies in both emerging and developed economies. Moreover, such strategy is often linked to innovation. Thus, sustainability and innovation have been characterized as 'sustainability-led innovation' [Hansen et al. (2009); Spitzeck et al. (2013)] or "innovating for sustainability" [Adams et al. (2012)].

However, up to the present time and in the context of innovation theory, there has been no study that has attempted to combine the growing scholarly topic of dynamic capabilities with the equally important topic of sustainability strategy. If the evidence on the relationship between dynamic capabilities and business performance is correct, then it is surprising that there has been no attempt to consider the strategic options available on innovation in relation to sustainable strategy. The purpose of this paper is to explore the nature of this connection and examine the implications for companies. Is it possible that the two major topic areas of dynamic capabilities and sustainability strategy can be mutually supportive of each other from an innovation perspective? Does it make a difference if companies are located in emerging markets rather than developed countries?

This paper undertakes this task by examining the two topics separately and then seeking to identify the innovation connections between them. The paper then employs dynamic capabilities concepts and innovation opportunity constructs to make a significant new contribution by developing four possible innovation strategies that explicate the link. The four areas are distinguished by the nature of the dynamic resource capabilities possessed by the company and by the type of sustainability strategy opportunities available to the individual company. The paper argues that such an innovation link can be applied regardless of whether the company is located in an emerging economy or in a developed economy. However, it identifies some differences in innovation strategy that are likely to be present depending on country geographic location. Thus, the paper contributes new knowledge by identifying and expanding on the new and important innovation strategy links between dynamic capabilities and sustainability strategy. It offers theoretical insights into the nature of that connection in the context of developed and developing economies. 
The paper is structured in the following way. The next section reviews the relevant literature on dynamic capabilities and sustainability strategy. The following section identifies the innovation link between the two topics and explores the nature of that link. The final section discusses the findings and offers some conclusions.

\section{Literature Review}

\subsection{Dynamic capabilities: Definition and implications}

Over the last few years, there has been considerable scholarly interest in the concept of dynamic capabilities. This has resulted in at least three bibliometric reviews on different aspects of dynamic capabilities [Barreto (2010); Helfat and Martin (2015); Vogel and Güttel (2013)] in addition to the two meta-analyses that examine business performance and dynamic capabilities [Fainshmidt et al. (2016); Karna et al. (2016)].

Dynamic capabilities developed out of the earlier strategic concept of the resource-based view (RBV) of the competitive resources of companies. The RBV of the firm postulates that the resources of the firm that are valuable, rare and difficult to imitate are the source of the competitive advantage of firms: they will result in superior business performance [Wernerfelt (1984); Barney (1991)]. However, the RBV makes the simplifying assumption that competitive assets remain truly competitive in perpetuity: this was challenged by Teece et al. [1997]. These authors argued that firms need ordinary or operational capabilities that allow them to operate their chosen lines of business efficiently: the existing business. They further reasoned that companies need dynamic capabilities to help them to upgrade their existing operational resources and/or create new capabilities. Such resources are directed towards achieving significantly increased business performance [Winter (2003); Helfat and Winter (2011, p. 1244)].

Teece et al. [1997, p. 516] defined dynamic capabilities as "the firm's ability to integrate, build and reconfigure internal and external competences." Subsequently, Eisenhardt and Martin [2000, p. 1107] developed the concept further by exploring the process of dynamic capabilities and concluding that, they are "the organizational and strategic routines by which firms achieve new resource configurations." The later definition by Helfat et al. [2007, p. 4] defined the concept as, "the capacity of an organization to purposefully create, extend or modify its resource base." To summarize, the dynamic capabilities of the firm have both content and process characteristics. They involve the firm in making clear and purposeful decision-making with regard to the routines that will deliver further development of its competitive resource base. Table 1 summarizes some of the essential characteristics of dynamic capabilities.

In spite of the considerable interest in the concept of dynamic capabilities, there has been some concern about the lack of consensus on its basic theoretical components and even confusion on the construct itself [Ambrosini and Bowman (2009); Kraatz and Zajac (2001)]. Nevertheless, there is now a broadly agreed definition of the concept and a recognition of its new insights [see, for example, Pablo et al. (2007); Salunke et al. (2011); Zhan and Chen (2013); Karimi and Walter (2015); 
Table 1. Some characteristics of dynamic capabilities.

\begin{tabular}{|c|c|}
\hline Characteristic & Literature reference \\
\hline $\begin{array}{l}\text { Grounded in the past history and path dependency } \\
\text { of the firm }\end{array}$ & Teece et al. $[1997]$ \\
\hline Fundamentally both process and content oriented & Eisenhardt and Martin [2000] \\
\hline $\begin{array}{l}\text { Rely heavily on knowledge creation, knowledge } \\
\text { evolution and knowledge sharing inside the firm }\end{array}$ & Zollo and Winter [2002] \\
\hline $\begin{array}{l}\text { Knowledge creation and absorption, knowledge in- } \\
\text { tegration and knowledge reconfiguration }\end{array}$ & Verona and Ravasi [2002] \\
\hline $\begin{array}{l}\text { Fundamental process: Sensing, seizing and reconfi- } \\
\text { guring assets }\end{array}$ & Teece $[2007]$ \\
\hline $\begin{array}{l}\text { Leadership and senior managers crucial to the effec- } \\
\text { tive development of dynamic capabilities }\end{array}$ & Rosenbloom [2000] and Salvato [2003] \\
\hline Managerial capabilities & $\begin{array}{l}\text { Galunic and Eisenhardt [2001] and Helfat and } \\
\text { Raubitschek [2000] }\end{array}$ \\
\hline Entrepreneurial skills & $\begin{array}{l}\text { Cepeda and Vera [2007], Gilbert [2006] and } \\
\text { Karimi and Walter [2015] }\end{array}$ \\
\hline Learning and innovation processes & Vogel and Güttel [2013] \\
\hline Linked to radical innovation & $\begin{array}{l}\text { O'Connor and Demartino [2006] and O'Connor } \\
{[2008]}\end{array}$ \\
\hline
\end{tabular}

Bingham et al. (2015); Wilden and Gudergan (2015)]. In essence, the concept of dynamic capabilities has achieved a degree of maturity. However, the distinction between ordinary and dynamic capabilities has been described as being 'blurry' [Helfat and Winter (2011); Karna et al. (2016)]. If both ordinary and dynamic capabilities are important to delivering sustainability objectives, then this unclear distinction makes it more difficult to search for a possible bridge between the competitive resources of the firm and its sustainability strategy.

\subsection{Sustainability and sustainability strategy}

Sustainability concerns those activities of the firm involved in sustaining the earth's environment [Brundtland (1987); Hoffman and Georg (2012)]. The underpinning principle for companies is that sustainability is the goal, not necessarily profit maximization: sustainability needs to deliver economic value to the company but also value to the environment and to society in general. This has been captured in the phrase 'the triple bottom line' of company development [Elkington (1998)]. However, although each of the three elements has both costs and benefits, it remains unclear where the balance lies between these elements. It remains for the individual company to make the choices. Arguably, such choices may partially be based on their resources and capabilities. However, the 'triple bottom line' implies a wider judgement by companies on the culture and social values of the firm that go beyond profit maximization.

Over the last 30 years, sustainability has become a key business objective for many firms [Porter and Kramer (2011)]. Following Brundtland [1987]'s early exploration of the concept, the sustainability strategy of the firm can be defined as those activities of the firm that address its environmental and societal activity. Hence, sustainability strategy captures the degree to which companies are actively 
employing sustainability principles as part of their business purpose [Bonini and Corner (2011)].

As a result of both government policy and increased stakeholder pressure, companies face increasing demands to satisfy the strong external pressures for greater sustainability policies in their companies. The various United Nations global accords have ensured that such pressure on companies applies in both the developing and developed world [United Nations (2015)]. Thus, for example at the company level, the global beverage products company Coca-Cola summarized its position in 2016: "Our publicly reported 2020 Sustainability Commitments drive us to continually improve. We aim to achieve our commitments through a concerted effort by The Coca-Cola Company and nearly 250 bottling partners in more than 200 countries and territories. We have set ambitious targets to drive system-wide change beyond small operational improvements." [Coca-Cola (2016)].

The worldwide pressure on companies for more sustainable use of the earth's resources has influenced firms in at least three ways: First, it has prompted product and process innovation; second, governments and institutional directives have introduced new sustainability legislation; third, at least some firms have recognized that they need to consider their contribution to society and not just to their profit delivery to their shareholders [Brundtland (1987); Elkington (1998); Seebode et al. (2012)]. In summary, the challenge for companies is how to develop and implement a strategy for sustainability: the main areas that need to be addressed are summarized in Table 2.

Sustainability strategy requires four main areas of skills and capabilities [Lynch (2015)]. Companies need to possess organizational capabilities if the benefits of sustainability are to be delivered [Sharma and Vredenburg (1998)]. In addition, companies also need to have the absorptive capacity to assimilate new information on sustainability [Delmas et al. (2011)]. They must also possess or develop the complementary assets that are required to develop and market sustainability [Christmann (2000)]. Finally, many scholars argue that the company needs to be able to develop its innovation processes in connection with the new technologies that will deliver sustainability [Adams et al. (2012)]. The outcome of such considerations, according to one study, is that new sustainable business activities were worth $\$ 4.5$ trillion in 2007 and were projected to grow to $\$ 6.4$ trillion by 2015 [Innovas (2009)].

Table 2. The purpose of sustainability strategy.

\begin{tabular}{l} 
Effective use of energy with moves towards electrification \\
Sustainable use of natural resources \\
Protection of the biosphere and development of carbon neutral organizations \\
Country self-sufficiency: Less reliance on imports \\
Greater energy and resource efficiency \\
Reduction and disposal of waste \\
Change of attitudes and lifestyles \\
\hline
\end{tabular}

Source: Adapted from Hart [1997] and Hoffman and Georg [2013]. 


\section{Discussion: The Possible Bridging Role of Innovation}

From a theoretical perspective, dynamic capability concepts are essentially derived from the economic theory of the firm. Such notions are grounded in the underpinning principles of economics including the assumption of profit maximization at the level of the firm [Penrose (1959); Porter (1991); Teece et al. (1997)]. Thus, such concepts do not directly address sustainability strategy with its broader purpose of the triple bottom line [Elkington (1998)]. Conversely, theories of sustainability lack clarity in relation to the benefits and costs to companies and the balance between them [Hoffman and Georg (2012)]. From a strategy practice perspective, there is a strong case for firms to develop increased sustainability strategy for three reasons: government policy and legislation; business opportunity; consumer pressure. However, the potentially high investment needed to deliver some areas of sustainability strategy may make opportunities challenging [Adams et al. (2012)]. None of these three areas suggests an obvious bridge between the concepts of dynamic capabilities and sustainable strategy.

Although there is a significant gap in our knowledge thus far to link dynamic capabilities and sustainability strategy, this does not mean that such a link cannot be found. There are at least three linking mechanisms: first, institutional theory [Lynch and Jin (2016); North (2005); Scott (2001)]; second, knowledge and learning theory [Grant (1996); Kogut and Zander (1992); Levinthal and March (1993); Nonaka and Takeuchi, 1991]; third, innovation strategy [Blum-Kusterer and Hussain (2001); Hansen et al. (2009); Seebode et al. (2012)]. Other linking mechanisms are also possible. It is beyond the scope of this paper to review all possible links. This paper focuses on innovation strategy within the topic of sustainability, because, "A new wave of system innovation is underway requiring leaders and managers to develop new kinds of knowledge and skills, and work across traditional boundaries, which is reshaping the relationship between business and society globally," [Seebode et al. (2012, p. 199)]. Thus, from a business perspective, sustainability strategy continues to deliver substantial new business but needs innovation. From a theoretical perspective, sustainability strategy may involve 'sensing, seizing and reconfiguring' company resources in the context of sustainable innovation [Lynch (2015); Teece (2007)]. Such logic and evidence supports a link between the dynamic capabilities of the firm and its sustainable strategies focused on the innovation strategies of the firm especially with regard to those linked to new sustainable opportunities.

However, the link between dynamic capabilities and sustainability strategy posses at least three potential problems as identified earlier in this paper. First, there is the blurred definition of dynamic capabilities. Second, the benefits and costs of sustainability strategy may be ill-defined. Third, the profit-maximizing objectives of the firm are not necessarily the same as those of the other stakeholders in the society in which the firm operates. This paper argues that the options presented by an innovation strategy approach provide a means, at least partially, of addressing these issues. The focus on the innovation strategy will help to narrow the focus of dynamic capabilities. A more precise and deeper definition of innovation strategy will assist in 
overcoming the problems associated with the costs and benefits of sustainability. Further definition of the precise purpose of the company with respect to innovation will assist in balancing the demands of the various company stakeholders with regard to sustainability [Lynch (2015)].

Although scholars have linked innovation and sustainability [Blum-Kusterer and Hussain (2001); Hansen et al. (2009); Seebode et al. (2012)] and have distinguished between ordinary and dynamic capabilities [Karna et al. (2016); Teece (2010)], the dynamics of sustainability strategy and innovation represents a new, strategic challenge for companies in both developed and developing markets. To explore this challenge, it is necessary to analyze the company routines that involve sensing, seizing and reconfiguring resources. The reason is that such capabilities are also likely to involve, "Opportunism [that] is controlled not just through metrics and monitoring, but also through high commitment cultures [and] values." [Teece (2010, p. 719)]. Hence, sustainability strategies are inherently linked to innovation strategies. Moreover, sustainability strategies at the present time are likely to deliver new sustainable business opportunities [Innovas (2009); United Nations (2013)]. Such opportunities may derive from both market pull and technology push innovation approaches [Di Stefano et al. (2012); Horbach et al. (2009)].

\section{Conclusion: The Innovation Sustainability Matrix}

\subsection{Developing the innovation resource-based options}

In order to explore the nature of the innovation opportunities that are possible, this paper now combines the three main areas previously identified in this paper. First, there is a need to distinguish between ordinary and dynamic capabilities of the firm [Helfat and Winter (2011)]. Second, within the sustainability strategy opportunities available to the firm, we can differentiate between the 'pull' of market sustainability opportunities and the 'push' of technological sustainability opportunities at the firm [Di Stefano et al. (2012)]. Third, from an innovation perspective itself, it is relevant to employ the widely accepted distinction between exploration and exploitation innovation [Lavie et al. (2010)].

Combining these considerations together, we can identify four innovation strategies that relate market and technology opportunities in sustainability to ordinary and dynamic capabilities these are shown in Fig. 1 and explored as follows:

- Fundamental innovation strategies: Explore and develop long-term technical innovation and R\&D strategies. The nature of such innovative activity will involve the development of new technologies. Typical strategies in this area will include the strategies of those companies engaged in new forms of sustainable energy generation from wind and tidal activity. The resources of such companies are wholly focused on exploring new opportunities that rely largely on their existing capabilities and routines and market opportunities. They may also employ dynamic capabilities but that is not the essence of their resource activity.

- Radical innovation strategies: Explore and seize technical and non-technical flexible opportunities plus institutional opportunities and threats. Companies 


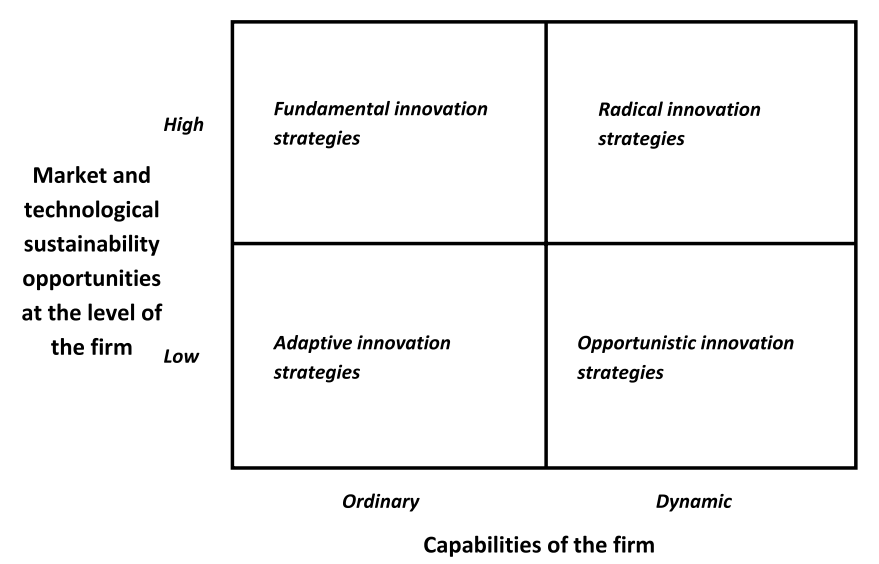

Fig. 1. Innovation sustainability matrix: Linking sustainability strategy to dynamic capabilities.

engaged in this area will define themselves as being engaged in radical moves into new areas, often involving both technological sustainability and market opportunity. Typical companies in this area will be engaged in ground-breaking innovation with the requirement to invest and develop wholly new company resources. Typical innovation strategies will encompass radical new areas of sustainable development such as those associated with new car engines. Institutional pressures such as government legislation on sustainability may have a significant impact on innovation in this area.

- Adaptive innovation strategies: Exploit market and institutional innovation opportunities. Inevitably, there will be some companies that will have more limited opportunity for sustainability initiatives, including those engaged in delivering some service activities like banking and finance. Some innovation may be possible but it will essentially encompass adapting to institutional pressures including government legislation. Sustainability opportunities will be more limited and essentially involve the exploitation of existing areas. Such companies will typically have resources that adapt and respond on a regular basis to sustainability pressures. However, they do not regard this as the prime focus of the strategy of the company.

- Opportunistic innovation strategies: Exploit and seize short-term technical, market and institutional opportunities. Some companies like food, consumer products and packaging companies may not have major opportunities to develop new areas of sustainability. However, they may take a pro-active approach to the search for new opportunities. This may potentially entail a radical and innovative reconfiguration of their resource capabilities. Such a process will be enhanced by flexible innovation strategies that seek out opportunities wherever they may occur.

\subsection{The innovation sustainability matrix for emerging market companies}

Emerging market companies may benefit from the natural resources of the home country, such as low energy costs, and also from their location in countries that have 
low labor costs [Dunning and Lundan (2008)]. In addition, these may provide some sustainability opportunities — for example, large field-array desert solar power generation in some North African countries. However, the home markets of emerging market companies are also likely to have lower wealth per head than developed countries and therefore have difficulty in investing in some sustainability developments [World Bank (2015)]. Moreover, some emerging market companies have not invested in R\&D to the same extent as their developed country competitors and therefore lack the technology base and knowledge base of companies from more developed countries. There is some evidence that the acquisition and development of such skills has not proved easy for EM MNCs [Zhu et al. (2011); Wright et al. (2005)], but they are essential for success [Helfat and Martin (2015)]. This implies that companies from emerging markets may benefit from focusing on the two sectors of the Innovation Sustainability Matrix that rely less on prior, technology-based resources and more on market opportunities: namely, opportunistic strategies and radical, non-technology strategies. But, the underpinning principle remains one of linking innovation in all its forms with sustainability strategy.

\section{References}

Adams, R., Jeanrenaud, S., Bessant, J., Overy, P. and Denyer, D. (2012). Innovating for sustainability: A systematic review of the body of knowledge. Network for Business Sustainability. Available at http://nbs.net/wp-content/uploads/NBS-Systematic-Review-Innovation.pdf.

Ambrosini, V. and Bowman, C. (2009). What are dynamic capabilities and are they a useful construct in strategic management? International Journal of Management Reviews, 11, 1: $29-49$.

Barney, J. B. (1991). Firm resources and sustained competitive advantage. Journal of Management, 17: 99-120.

Barreto, I. (2010). Dynamic capabilities: A review of past research and an agenda for the future. Journal of Management, 36, 1: 256-280.

Bingham, C. B., Heimeriks, K. H. and Schijven, M. (2015). Concurrent learning: How firms develop multiple dynamic capabilities in parallel, Strategic Management Journal, 36: $1802-1825$.

Blum-Kusterer, M. and Hussain, S. S. (2001). Innovation and corporate sustainability: An investigation into the process of change in the pharmaceutical industry. Business Strategy and the Environment, 10: 300-316.

Bonini, S. and Corner, S. (2011). McKinsey global survey results: The business of sustainability. McKinsey Quarterly. Available at https://www.mckinseyquarterly.com/ The_business_of_sustainability_McKinsey Global_Survey_results_2867.

Brundtland, G. H. (1987). Our common future: Call for action. Environmental Conservation, 14, 4: 291-294.

Cepeda, G. and Vera, D. (2007). Dynamic capabilities and operational capabilities: A knowledge management perspective. Journal of Business Research, 60: 426-437.

Christmann, P. (2000). Effects of "best practices" of environmental management on cost advantage: The role of complementary assets. Academy of Management Journal, 43, 4: $663-680$.

Coca-Cola (2016). Sustainability Report: Assuring the Accuracy of our Disclosures. Sourced on 1st October 2016. Available at http://www.coca-colacompany.com/stories/2020sustainability-commitments. 
Delmas, M., Hoffmann, V. H. and Kuss, M. (2011). Under the tip of the iceberg: Absorptive capacity, environmental strategy, and competitive advantage. Business and Society, 50, 1: $116-154$.

Di Stefano, G., Gambardella, A. and Verona, G. (2012). Technology push and demand pull perspectives in innovation studies: Current findings and future research directions. Research Policy, 41: 1283-1295.

Di Stefano, G., Peteraf, M. and Verona, G. (2014). The organizational drivetrain: A road to integration of dynamic capabilities research. The Academy of Management Perspectives, 28, 4: 307-327.

Dunning, J. H. and Lundan, S. M. (2008). Multinational Enterprises and the Global Economy, 2nd Edition. Edward Elgar, Cheltenham.

Eisenhardt, K. M. and Martin, J. A. (2000). Dynamic capabilities: What are they? Strategic Management Journal, 21: 1105-1121.

Elkington, J. (1998). Cannibals with Forks: The Triple Bottom Line of 21st Century Business. New Society Publishers, Philadelphia, PA.

Fainshmidt, S., Pezeshkan, A., Frazier, M. L., Nair, A. and Markowski, E. (2016). Dynamic capabilities and organizational performance: A meta-analytic evaluation and extension. Journal of Management Studies, 53, 8: 1348-1380.

Galunic, C. and Eisenhardt, K. M. (2001). Architectural innovation and modular corporate forms. Academy of Management Journal, 44, 6: 1229-1250.

Gilbert, C. G. (2006). Change in the presence of residual fit: Can competing frames coexist?. Organization Science, 17, 1: 150-167.

Grant, R. (1996). Toward a knowledge-based theory of the firm. Strategic Management Journal, 17: 109-122.

Hansen, E. G., Grosse-Dunker, F. and Reichwald, R. (2009). Sustainability innovation cube - A framework to evaluate sustainability-oriented innovations. International Journal of Innovation Management, 13, 4: 683-713.

Hart, S. (1997). Beyond greening: Strategies for a sustainable world. Harvard Business Review, Reprint 97105, accessed free on the web courtesy of Vestas.

Helfat, C. E., Finkelstein, S., Mitchell, W., Peteraf, M. A., Sing, H., Teece, D. J. and Winter, S. G. (2007). Dynamic Capabilities: Understanding Strategic Change in Organizations. Blackwell Publishing, Malden, MA.

Helfat, C. E. and Martin, J. A. (2015). Dynamic managerial capabilities: Review and assessment of managerial impact on strategic change, Journal of Management, 41, (5): $1281-1312$.

Helfat, C. E. and Raubitschek, R. S. (2000). Product sequencing: Co-evolution of knowledge, capabilities and products. Strategic Management Journal, 21, 10-11: 961-979.

Helfat, C. E. and Winter, S. G. (2011). Untangling dynamic and operational capabilities: Strategy for the (n)ever-changing world. Strategic Management Journal, 32, 11: $1243-1250$.

Hoffman, A. J. and Georg, S. (2012). Introduction to business and the natural environment. In Hoffman, A. J. and Georg, S. (eds.), Business and the Natural Environment, Chapter 1. Routledge, London.

Horbach, J., Rammer C. and Rennings, K. (2009). Determinants of eco-innovations by type of environmental impact, the role of regulatory push/pull, technology push and market pull, Centre for European Economic Research. Discussion Paper No. 11-027, [accessed on November 2016] via ftp://ftp.zew.de/pub/zew-docs/dp/dp11027.pdf.

Innovas Solutions Ltd. (2009). Low Carbon and Environmental Goods and Services: An Industry Analysis, Report, London. Sourced from the web at www.berr.gov.uk/files/ file50253.pdf.

Karimi, J. and Walter, Z. (2015). The role of dynamic capabilities in responding to digital disruption: A factor-based study of the newspaper industry. Journal of Management Information Systems, 32, 1: 39-81. 
Karna, A., Richter, A. and Reisenkampff, E. (2016). Revisiting the role of the environment in the capabilities-financial performance relationship: A meta-analysis. Strategic Management Journal, 37: 1154-1173.

Kogut, B. and Zander, U. (1992). Knowledge of the firm, combinative capabilities, and the replication of technology. Organization Science, 3, 3: 383-397.

Kraatz, M. S. and Zajac, E. J. (2001). How organizational resources affect strategic change and performance in turbulent environments; theory and evidence. Organization Science, 12: $632-657$.

Lavie, D., Stettner, U. and Tushman, M. L. (2010). Exploration and exploitation within and across organizations. Academy of Management Annals, 4: 109-155.

Levinthal, D. A. and March, J. G. (1993). The myopia of learning. Strategic Management Journal, 14, Winter: 95-112.

Lynch, R. (2015). Green strategy. Strategic Management, 7th Edition, Chapter 14. Pearson Education, Harlow.

Lynch, R. and Jin, Z. (2016). Exploring the institutional perspective on international business expansion: Towards a more detailed conceptual framework. Journal of Innovation and Knowledge, 1, 2: 117-124.

Nonaka, I. and Takeuchi, H. (1995). The Knowledge-Creating Company: How Japanese Companies Create the Dynamics of Innovation. Oxford University Press, Oxford.

North, D. C. (2005). Understanding the Process of Economic Change. Princeton University Press, Princeton, NJ.

O'Connor, G. C. (2008). Major innovation as a dynamic capability: A systems approach. Journal of Product Innovation Management, 25: 313-330.

O'Connor, G. C. and Demartino, R. (2006). Organizing for radical innovation: An exploratory study of the structural aspects of RI management systems in large established firms. Journal of Product Innovation Management, 23: 475-497.

Pablo, A. L., Reay, T., Dewald, J. R. and Casebeer, A. L. (2007). Identifying, enabling and managing dynamic capabilities in the public sector. Journal of Management Studies, 44, 5: $687-708$.

Penrose, E. T. (1959). The Theory of Growth of the Firm. Wiley, New York.

Porter, M. E. (1991). Towards a dynamic theory of strategy. Strategic Management Journal, 12, Winter: 95-117.

Porter, M. E. and Kramer, M. R. (2011) Creating shared value, Harvard Business Review, 89, 1-2: $62-77$.

Rosenbloom, R. S. (2000). Leadership, capabilities, and technological change: The transformation of NCR in the electronic era. Strategic Management Journal, 21: 1083-1103.

Salunke, S., Weerawardena, J. and McColl-Kennedy, J. R. (2011). Towards a model of dynamic capabilities in innovation-based competitive strategy: Insights from projectoriented service firms. Industrial Marketing Management, 40, 8: 1251-1263.

Salvato, C. (2009). Capabilities unveiled: The role of ordinary activities in the evolution of product development processes. Organization Science, 20: 384-409.

Scott, W. R. (2001). Institutions and Organizations. Sage Publications, Thousand Oaks, CA.

Seebode, D., Jeanrenaud, S. and Bessant, J. (2012). Managing innovation for sustainability. RED Management 42, 3: 195-206.

Sharma, S. and Vredenburg, H. (1998). Proactive corporate environmental strategy and the development of competitively valuable organizational capabilities. Strategic Management Journal, 19, 8: 729-753.

Spitzeck, H., Boechat, C. and Leão, S. F. (2013). Sustainability as a driver for innovation towards a model of corporate social entrepreneurship at Odebrecht in Brazil. Corporate Governance, 13, 5: 613-625.

Teece, D. (2007). Explicating dynamic capabilities: The nature and microfoundations of (sustainable) enterprise performance. Strategic Management Journal, 28: 1319-1350. 
Teece, D. J. (2010). Technological innovation and the theory of the firm: The role of enterprise-level knowledge, complementarities and (dynamic) capabilities. In Hall, B. H. and Rosenberg, N. (eds.), Handbook of the Economics of Innovation, Chapter 16. Elsevier, Amsterdam.

Teece, D. J., Pisano, G. and Shuen, A. (1997). Dynamic capabilities and strategic management. Strategic Management Journal, 18, 7: 509-533.

United Nations Environment Program (2011). Towards a Green Economy: Pathways to Sustainable Development and Poverty Eradication. Retrieved from www.unep.org/ greeneconomy.

United Nations Department of Economic Affairs (2013). UN World Economic and Social Survey 2013: Sustainable Development Challenges.

Verona, G. and Ravasi, D. (2003). Unbundling dynamic capabilities: An exploratory study of continuous product innovation. Industrial and Corporate Change, 12: 577-606.

Vogel, R. and Güttel, W. H. (2013). The dynamic capability view in strategic management: A bibliometric review. International Journal of Management Reviews, 15: 426-446.

Wernerfelt, B. (1984). A resource-based view of the firm, Strategic Management Journal, 5, 2: 171-180.

Wilden, R. and Gudergan, S. P. (2015). The impact of dynamic capabilities on operational marketing and technological capabilities: Investigating the role of environmental turbulence. Journal of the Academy Marketing Science, 43: 181-199.

Winter, S. (2003). Understanding dynamic capabilities. Strategic Management Journal, 24: 991-995.

World Bank (2015). Annual Report, 2015. Retrieved on 28 November 2016 from https:// openknowledge.worldbank.org/handle/10986/22550.

Wright, M., Filatotchev, I., Hoskisson, R. and Peng, M. (2005). Guest editors introduction: Strategy research in emerging economies: Challenging the conventional wisdom. Journal of Management Studies, 42: 1-33.

Zhan, W. and Chen, R. (2013). Dynamic capability and IJV performance: The effect of exploitation and exploration capabilities. Asia Pacific Journal of Management, 30: 601-632.

Zhu, Y., Lynch, R. and Jin, Z. (2011). Playing the game of catching-up: Global strategy building in a Chinese company. Asia Pacific Business Review, 17, 4: 511-533.

Zollo, M. and Winter, S. (2002). Deliberate learning and the evolution of dynamic capabilities. Organization Science, 13: 339-351.

\section{Biography}

Richard Lynch is Emeritus Professor of Strategic Management at Middlesex University London, England. He originally studied at UMIST, Leeds University and the London Business School. He worked for over 20 years in business with wellknown companies such as J Walter Thompson, General Foods (now part of Mendelez) and Dalgety Spillers (now part owned by Nestlé) in positions in marketing and strategic management. He has been involved in higher education for over 30 years and written five books on international marketing and strategy, in addition to eight editions of the text book Strategic Management published by Pearson Education. His current research interests focus on global strategy, particularly with regard to developing countries and sustainability. He has published in the Journal of Business Research, Asia Pacific Business Review, International Business Review, Management Research Review, Thunderbird International Business Review, Management Decision, Journal of Innovation and Knowledge, among others. 